\title{
The Role Of Intellectual Capital In Modernizing The Influence Of Good Corporate Governance And Sharia Compliance Of Sharia Banks
}

\author{
Iva Nur Azizah', Yayu Putri Senjani² \\ 1,2Universitas Islam Negeri Sunan Kalijaga Yogyakarta, Indonesia \\ ivanurazizah0@gmail.com
}

\begin{abstract}
Purpose - Improved financial performance of Islamic banks can be done by improving the system of corporate governance and sharia compliance. In addition to a good corporate governance system and sharia compliance, other factors such as intellectual capital in sharia banks can also improve financial performance. The purpose of this study was to determine the role of intellectual capital in moderating the effect of good corporate governance and sharia compliance on financial performance of sharia banks in 20132017.
\end{abstract}

Method - Sampling technique used is purposive sampling. The analytical technique used is panel data regression test with software Eviews 9 .

Result - It is found that good corporate governance and Islamic Income Ratio have an effect on the financial performance of sharia banks which is poxied by return on assets. Besides that, intellectual capital modernizesgood corporate governance and Islamic Income Ratio on the financial performance of sharia banks, but it does not modernize sharia compliance which is proxied with Profit Sharing Ratio (PSR) and Zakat Performing Ratio (ZPR).

Implication - This study uses the data from 14 islamic commercial banks in Indonesia.

Originality - The papers look into the role of intellectual capital variables in the relationship of good corporate governance and sharia compliance to the financial performance.

Keywords: Good Corporate Governance; Sharia Compliance; Intellectual Capital; Return on Assets. 
Iva Nur Azizah, Yayu Putri Senjani

\section{Introduction}

Islamic financial institutions in Indonesia continue to grow from year to year. The largest assets are owned by sharia shares while sharia banking occupies the second position in ownership of assets in Islamic financial institutions. If seen from the total assets owned by Islamic financial institutions consisting of sharia banking, sharia insurance, sharia financing, non-bank institutions, corporate sukuk, sharia mutual funds, state sukuk, and sharia shares have increased (OJK, 2017).

Sharia banking consists of Sharia Commercial Banks (BUS), Sharia Business Units (UUS), and Sharia People Financing Banks (Sharia Rural Banks). According to the Financial Services Authority (OJK) sharia banking assets in 2017 grew 18.97\%, although the growth rate is still high but tends to slow down compared to 2016 which grew by $20.28 \%$. The factor that most influenced the slowing growth of sharia banking was due to the growth of sharia commercial banks which decreased by $5.78 \%$. Slowing growth in BUS has a major impact on the total growth of the Islamic banking industry because BUS assets dominate the national sharia banking asset composition by $66.21 \%$. Meanwhile, the value of Return on Assets (ROA) increased from $0.95 \%$ to $1.17 \%$ in 2017 (OJK, 2017).

Improved financial performance at financial institutions can be caused by various factors. According to Arafat in Fabiola (2018) states that good corporate governance is useful for improving financial performance. In addition, according to Ulum (2009), intellectual capital also has an influence on company performance. Thus, if intellectual capital, human resources, good corporate governance and obedience to sharia principles in sharia banking run well, stakeholders will increasingly trust sharia banking, so that the market share and financial performance of sharia banks in Indonesia will increase.

Many researches have been done to recognize the factors that influence financial performance. From various studies that have been conducted, it is concluded that among the factors that can affect the financial performance of 
The Role Of Intellectual Capital In ...

companies includes intellectual capital, good corporate governance, sharia compliance, debt to equity, and enterprise risk management. According to Chen and Shimerda in Fahmi (2012), they stated that financial ratios are an important part to evaluate the performance and financial condition of an entity. Financial ratios are often used as an analytical tool to see the condition of a company's financial performance. In addition to financial ratios, other approaches are needed to assess financial performance such as the quality of Human Resources (HR) and company management.

Human Resources (HR) can be measured by intellectual capital. According to previous research, intellectual capital is included in the category of intangible assets that can affect a company's performance. Ozkan, Cakan, and Kayacan (2016) found that intellectual capital influenced the financial performance of banks in Pakistan. At different Loci, Kurfi, Udin, and Bahamman (2017) also found that intellectual capital had a positive influence on the financial performance of banks in Bahrain. While on the different side, Winahyu and Mimba (2018) concluded that intellectual capital strengthened the effect of debt to equity ratio on profitability, and intellectual capital weakened the effect of company size on the profitability of property and real estate companies. According to Khan and Ali (2017) companies with intellectual capital made corporate risk management practices positively affect the company's operating and market performance. Thus, the influence of Enterprise Risk Management (ERM) and intellectual capital can improve company performance.

Beside of Human Resources (HR), factors that can affect the financial performance of Islamic banking are company management in implementing Good Corporate Governance (GCG). Good Corporate Governance is an important element in companies as well as Islamic banks. Management of a company is seen from the implementation of Good Corporate Governance. Pallegrini, Grais, and Matteo (2006) found that the bankruptcy of Ihlas Finance House, the largest financial institution in Turkey in 2001, Islamic banks in South Africa, sharia companies in Egypt, financial difficulties at the Islamic Bank of Dubai and Islamic Bank of Malaysia Berhard, allegedly is 
Iva Nur Azizah, Yayu Putri Senjani

caused by weaknesses in corporate governance, mechanisms, and inobedience to sharia.

According to Noordin and Kassim (2015), the implementation of good corporate governance contributed to improving company performance. Heider, Khan, and Iqbal (2015) from the results of their research showed that various corporate governance variables had a positive effect on the financial performance of Islamic financial institutions in Pakistan. In addition, Zakiah (2018) from his research results showed that sharia compliance strengthened the relationship between GCG with return on assets (ROA) and return on equity (ROE).

Apart from implementing good corporate governance that illustrates the financial performance of Islamic financial institutions, the quality of human resources working in Islamic financial institutions also affects the financial performance of Islamic financial institutions. Efforts to improve the quantity and quality of human resources are aimed at all parties that play an active role in the development and operation of sharia banking, which includes sharia bank managers, sharia bank supervisors, members of the Sharia Supervisory Board (DPS), and the judiciary handling disputes in sharia banking (OJK: 2017).

On the sharia compliance side, sharia financial institutions have a structural role to give sharia compliance opinions in financial statements,As stated in the Financial Services Authority Regulation No. 8 / POJK. 03/2014 concerning Implementation of GCG for Commercial Banks. Each bank is required to conduct a self assessment of the implementation of GCG; prepare reports on the implementation of GCG periodically; and then will be assessed by Bank Indonesia. Implementation of good corporate governance in the sharia banking industry must meet sharia principles (sharia compliance).

Sharia compliance is a mandatory element that must be obeyed by Islamic financial institutions. Sharia compliance has an influence on the financial performance of Islamic banking. Pepis and Jong (2018) found that sharia compliance positively affected long-term financial performance as 
evidenced by the increased value in return on assets (ROA) and return on sales (ROS). Akguc and Rahahleh (2018) from their research found that companies that implement sharia compliance were more profitable than companies that did not implement sharia compliance. This can be seen from the average Return on Assets (ROA) where companies that implement sharia compliance have a higher return on assets (ROA) compared to companies that do not apply sharia compliance, which is around $2.8 \%$ to $4.3 \%$ of assets.

In previous studies, researchers used the variables of intellectual capital, sharia compliance, good corporate governance, and debt to equity ratio, enterprise risk management that affects financial performance. The results showed that these variables have an influence on financial performance in various Islamic companies and financial institutions. Whereas in this study the authors will examine the role of intellectual capital variables, whether to strengthen or weaken the relationship of good corporate governance and sharia compliance to the financial performance of Islamic commercial banks in Indonesia. Based on the description above, the researcher will conduct a study entitled "The role of intellectual capital in moderating the influence of good corporate governance and sharia compliance on the financial performance of Islamic banking" with the object of Islamic commercial banks in Indonesia in 2013-2017.

The purpose of this study is to determine the role of intellectual capital in modernizing the influence of good corporate governance and sharia compliance on financial performance in Islamic commercial banks based on the research objectives.The researchers hope that the results of this study can provide theoretical and practical uses. This research is expected to provide benefits for Islamic commercial banks in improving financial performance through the application of intellectual capital owned by HR in Islamic commercial banks, implementation of good corporate governance, and compliance with sharia principles (sharia compliance). It also can increase knowledge about the role of intellectual capital in modernizing the effect of implementing good corporate governance and sharia compliance on the 
Iva Nur Azizah, Yayu Putri Senjani

financial performance of Islamic commercial banks and then developed it for further research.

\section{Literature Review}

The theoretical foundation in this research is stakeholders theory and resource base view theory. The stakeholder theories used are those proposed by Freeman and Reed (1983). Based on stakeholder theory, organizational management is expected to carry out activities deemed important by stakeholders and report back on those activities to stakeholders. Watts and Zimmerman (1986) in Ulum (2009) state that the power of stakeholders to influence corporate management must be seen as a function of the level of stakeholder control over the resources needed by the organization. While resource base view theory, according to Wernerlfelt (1984), is a competitive advantage that mainly lies in a set of tangible or intangible company assets. Barney (1991) supports the conclusion that a company can achieve sustainable competitive advantage if it has unique resources. These resources are not easy to buy, transfer or copy. Simultaneously, its scarcity benefits the company.

Financial performance is an analysis conducted to see the extent to which a company has carried out the rules of financial implementation properly and correctly (Fahmi, 2012: 2). Understanding corporate governance according to Turnbull Report in Effendi (2016), corporate governance is defined as a system of internal control of the company which has the main goal of managing significant risks to meet its business objectives through securing company assets and increasing the value of shareholders' investments in the long term.

According to Ilhami (2009), sharia compliance is the fulfillment of all sharia principles in all activities conducted as a manifestation of the characteristics of the institution itself including sharia banks. Intellectual capital is referred to as value creation. Intangible value creation must get enough attention, because this has a very large impact on the overall performance of the company (Ulum, 2009: 85). 
The Role Of Intellectual Capital In ...

\section{Methods}

This type of research is collaborative or causal research. The purpose of this study is to determine whether there is correlation among variables or make predictions based on correlations among variables (Idriantoro and Supomo, 2014: 26). The dependent variable in this study is the financial performance of Islamic commercial banks in Indonesia. While the independent variables are good corporate governance and sharia compliance, and the moderating variable is intellectual capital. The objects used in this study are 14 Islamic commercial banks in Indonesia from 2013-2017. This study uses 70 annual reports and good corporate governance reports of Islamic commercial banks. The data are obtained through every official website of Islamic banks in Indonesia. The researcher selects the annual report which contains the variables used in this study.

Based on Financial Services Authority Regulation No.8 / POJK.03 / 2014 and Financial Services Authority Circular Letter No.10 / SEOJK.03 / 2014 concerning health assessments of sharia commercial banks and sharia business units, banks are required to conduct a self assessment of GCG implementation.

Sharia compliance is measured using Islamic income ratio (IIR) indicators, profit sharing ratio (PSR), zakat performance ratio (ZPR) (Hameed et al., 2004). The main goal of Islamic banking is profit sharing. Thus it is important to identify how Islamic banking has succeeded in achieving its objectives.

Hameed et al, (2004), bank wealth must be based on net assets rather than net income which has been emphasized in conventional methods. Therefore, if the assets owned by banks are higher, they will pay higher zakat as well. Hameed et al. (2004), beside of separating investment into Islam and non-Islam, income also requires the separation of Islam and non-Islam.

Financial performance is an analysis conducted to see the extent to which a company has carried out the rules of financial implementation properly and correctly (Fahmi, 2012: 2). Return on assets (ROA) is one of the performance 
Iva Nur Azizah, Yayu Putri Senjani

measures used to represent the financial performance of Islamic banking (Ozkan, Cakan, and Kayacan, 2017).

The modernizing variable in this study is a value added with intellectual captial (VAIC). VAIC indicates an organization's intellectual ability that can be considered as a business performance indicator (BPI). Value added intellectual capital (VAIC) is a component of the sum of capital employed efficiency (CEE), human capital efficiency (HCE), structural capital efficiency (SCE); CEE = VA/CE; HCE = VA/HC; SCE = SC/VA; Value Added (VA) = Output minus Input (business income and other income minus operating expenses and other cost except employee expenses); Capital Employed (CE) = available fund (equity and net income); Human Capital (HC) = employee expense; Structural Capital (SC) = VA - HC.

Sampling in this study used a purposive sampling method. According to Indriantoro and Supomo (2014: 131), purposive sampling is a type of nonrandom sample selection whose information is obtained using certain considerations. The data in this study include panel data from the combination of cross sectional and time series. This study uses three variables, namely the independent variable, the dependent variable, and the moderation variable which will be performed a descriptive statistical test, a test choosing panel data estimation technique, a panel data regression test, and a hypothesis test, a classic assumption test using Eviews software 9. Classic Assumption Test which consists of multicollinearity test and heteroscedivity test, $\mathrm{F}$ test, $\mathrm{T}$ test, coefficient of determination test. Panel data regression model used in this study is as follows:

$\mathrm{Y}=\alpha+\beta 1 \mathrm{X} 1+\beta 2 \mathrm{X} 2+\beta 3 \mathrm{X} 3+\beta 4 \mathrm{X} 4+\beta 5 \mathrm{Z}+\beta 7 \mathrm{X} 1 \mathrm{Z}+\beta 8 \mathrm{X} 2 \mathrm{Z}+\beta 9 \mathrm{X} 3 \mathrm{Z}+$ $\beta 10 \mathrm{X} 4 \mathrm{Z}+\mathrm{e}$

Explanation: $Y=$ Financial performance $(\mathrm{ROA}) ; \alpha=$ constant variable; $\beta=$ regression coefficient; X1 = Good Corporate Governance (GCG);X2 = Profit Sharing Ratio (PSR); X3 = Zakat Performing Ratio (ZPR); X4 = Islamic Income Ratio (IIR); Z = Value Added Intellectual Capital (VAIC); e = Error. 
The Role Of Intellectual Capital In ...

\section{Hypothesis}

The conceptual framework this study can be described as follows:

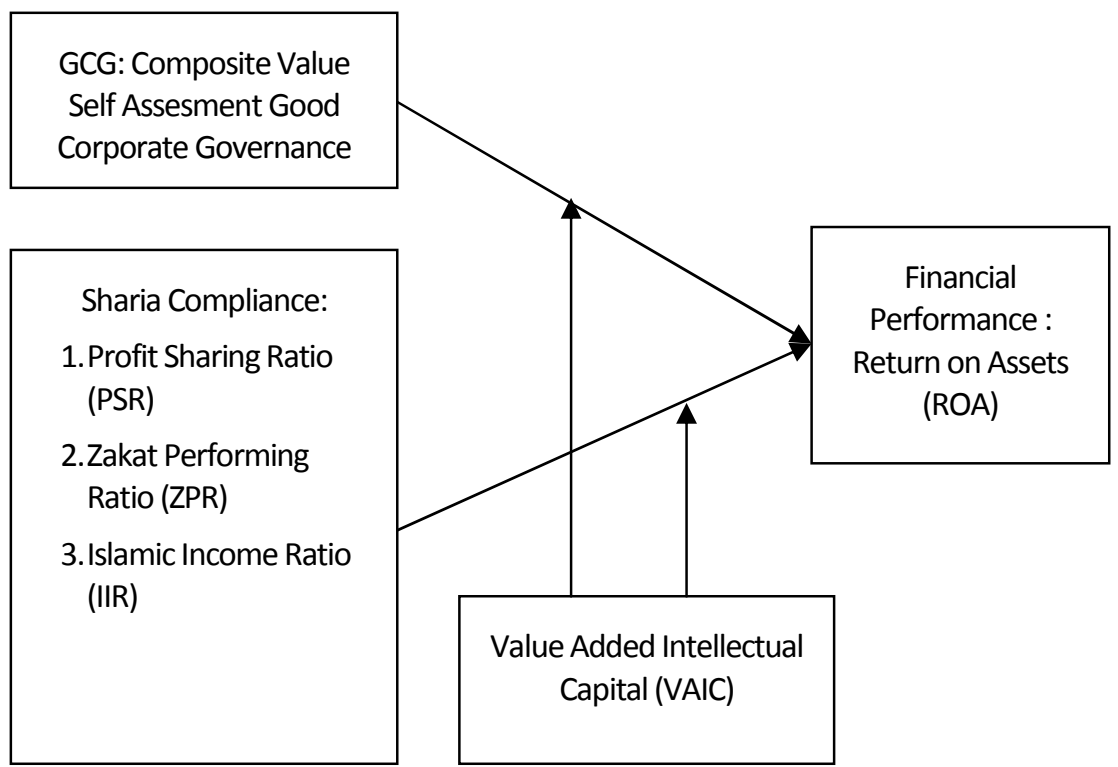

Figure 1. Research Framework

In the research of Haider, Khan, and Iqbal (2015), with the results, found that there was a positive relationship between the size of the board and audit committee and bank performance which is theoretically proven. The size of the audit committee can increase the company's financial performance. Interesting findings in this study have a negative influence and correlation between ROE and number of meetings. Board members' meetings hold various types of costs or expenses such as investment time management, travel expenses, meeting payments. However, board size is far more motivating to outsource personnel by contributing to the board and improving financial performance. Noordin and Kassim (2015) in their research found that there was a significant positive relationship between the number of directors and financial performance in construction companies. The measurement variables for good corporate governance are board size, the dual role of independent councils, the number of board meetings, the 
Iva Nur Azizah, Yayu Putri Senjani

existence of an audit committee, and the existence of a remuneration committee.

$\mathrm{H}_{1}$ : Good corporate governance positively affects to the financial performance of general sharia banking.

Pepis and Jong (2017) The results of their study found that sharia compliance positively affected financial performance. Based on Zakiah's research (2017) the results of her research found that sharia compliance strengthened the relationship between governance and return on assets (ROA) and return on equity (ROE) in Islamic banking. Nastion, Lubis, and Fachrudin (2018), the results showed that sharia compliance, Islamic corporate governance, Islamic social reporting disclosure affected financial performance in Islamic banks in Indonesia with profit sharing ratio (PSR), zakat performing ratio (ZPR) affect the Return on Asset (ROA), while the Islamic income ratio (IIR) had no influence on ROA.

$\mathrm{H}_{2 \mathrm{a}}$ : Profit sharing ratio (PSR) positively affects to the financial performance of general sharia bangking

$\mathrm{H}_{2 \mathrm{~b}}$ : Zakat performing ratio (ZPR) positively affects to the financial performance of general sharia bangking.

$\mathrm{H}_{2 \mathrm{c}}$ : Islamic income ratio (IIR) positively affects to the financial performance of general sharia bangking.

Intellectual capital is an intangible asset owned by a company. According to Kurfi, Udin, and Bahamman (2017) research results found that there is a significantly positive effect of intellectual capital on financial performance. Ozkan, Cakan, and Kayacan (2016), the results of this study indicated that intellectual capital influences the financial performance of banks in Istanbul with capital employed efficiency (CEE) and human capital efficiency (HCE) which positively influenced financial performance at banks. Winahyu and Mimba (2018) intellectual capital strengthened the effect of debt to equity ratio on profitability and intellectual capital weakened the effect of company size on the profitability of property and real estate companies. Intellectual capital moderates the debt to equity ratio (DER) and company size on return 
The Role Of Intellectual Capital In ...

on assets (ROA) which is a proxy for the profitability of property and real estate companies.

$\mathrm{H}_{3 \mathrm{a}}$ : intellectual capital modernizes the effect of good corporate governance (GCG) on financial performance of general sharia bank.

$\mathrm{H}_{3 \mathrm{~b}}$ : intellectual capital modernizes the effect of profit sharing ratio (PSR) on financial performance of general sharia bank.

$\mathrm{H}_{3 c}$ : intellectual capital modernizes the effect of zakat performing ratio (ZPR) on financial performance of general sharia bank.

$\mathrm{H}_{3 \mathrm{~d}}$ : intellectual capital modernizes the effect of islamic income ratio (IIR) on financial performance of general sharia bank.

\section{Results and Discussion}

Descriptive statistics is a process of transforming research data in tabular form so that it is easily understood and interpreted (Indriantoro and Supomo 2014: 170). The results of descriptive statistics in this study can be seen in the following table 1.

This is based on the three model test results that have been carried out, namely the chow test, the hausman test, the lagrange multiplier test - the best model chosen, the common effect model. From estimating panel data regression, this study chooses the common effect model to see the interaction of intellectual capital in either strengthening or weakening the influence of good corporate governance variables and sharia compliance variables on the financial performance of Islamic commercial banks.

Table 1. Descriptive Statistic

\begin{tabular}{lllllll}
\hline & ROA & GCG & PSR & ZPR & IIR & IC \\
\hline Mean & -0.059012 & 4.161333 & 0.463853 & 0.004051 & 0.868169 & 2.153023 \\
Median & 0.565456 & 4.185000 & 0.303334 & 0.000178 & 0.914102 & 1.565820 \\
Maximum & 11.85087 & 5.000000 & 5.525176 & 0.119485 & 0.996916 & 125.7933 \\
Minimum & -22.44592 & 3.000000 & 0.005832 & $9.38 \mathrm{E}-06$ & 0.319270 & 59.32928 \\
Std. Dev. & 4.281152 & 0.558243 & 0.736551 & 0.020569 & 0.151662 & 18.35714 \\
Observations & 60 & 60 & 60 & 60 & 60 & 60 \\
\hline
\end{tabular}


Iva Nur Azizah, Yayu Putri Senjani

Regression test results using the common effect model are as table 2.

Table 2. Common Effect Model

\begin{tabular}{lllll}
\hline Variable & Coefficient & Std. Error & t-Statistic & Prob. \\
\hline GCG & -18.13863 & 3.698478 & -4.904350 & 0.0000 \\
PSR & 2.303634 & 0.674465 & 3.415496 & 0.0013 \\
ZPR & -0.141744 & 0.511517 & -0.277106 & 0.7828 \\
IIR & -16.04914 & 39.29811 & -0.408395 & 0.6847 \\
IC & 10.22754 & 2.921944 & 3.500251 & 0.0010 \\
GCG*IC & 3.797855 & 0.556152 & 6.828802 & 0.0000 \\
PSR*IC & -0.548840 & 0.113746 & -4.825128 & 0.0000 \\
ZPR*IC & -0.033922 & 0.163712 & -0.207203 & 0.8367 \\
IIR*IC & 9.207913 & 20.18596 & 0.456154 & 0.6503 \\
\hline
\end{tabular}

\section{Hypothesis Test}

This research chooses the common effect model to see the interaction of intellectual capital in strengthening or weakening the influence of good corporate governance variables and sharia compliance variables on the financial performance of Islamic commercial banks in Indonesia. Hypothesis test results using the common effect model are as follows Table3. Based on table 3 , it shows that the probability value of the $\mathrm{F}$ test in this study is 0.0000 with a significance of the $\mathrm{F}$ test of $0.0000<0.05$ which means that overall the independent variable has an influence on the dependent variable.

Table 3. F Test

\begin{tabular}{llll}
\hline R-squared & 0.633794 & Mean dependent var & -0.059012 \\
Adjusted R-squared & 0.567877 & S.D. dependent var & 4.281152 \\
S.E. of regression & 2.814262 & Akaike info criterion & 5.058289 \\
F-statistic & 9.615007 & Durbin-Watson stat & 1.857541 \\
Prob (F-statistic) & 0.000000 & & \\
\hline
\end{tabular}


The table 3 also shows that the Adjusted R-Square value of 0.5678 , which means that it is $56.78 \%$. The ups and downs of financial performance at Islamic commercial banks are influenced by good corporate governance, sharia compliance, and intellectual capital. The remaining $43.78 \%$ is explained by other variables outside the regression model used.

The t test using the common effect model that has been carried out is as follows Table 2. Based on the tests conducted, the results showed that the variable of good corporate governance proxied by the composite value of self assessment affected the financial performance of Islamic commercial banks proxied by Return on Assets (ROA). The direction of the positive coefficient shows that the better the composite value of good corporate governance selfassessment, the financial performance of Islamic commercial banks which are proxied by Return on Assets (ROA) will grow. This result is in line with the objectives of stakeholder theory, which is aimed to help corporate managers understand their stakeholder environment and to manage more effectively amongst the relationships in their company environment.

However, the broader goal of stakeholder theory is to help relationship managers increase the value of their activities, and save losses for stakeholders. Improving good corporate governance at the company will improve company finances better too. If the company is better, then good corporate governance, the losses to be received by stakeholders will be minimal. This is in line with company goals such as Islamic commercial banks, to bring the welfare for all stakeholders.

This study is in line with the perspective of applying good corporate governance that explains without the implementation of effective corporate governance, Islamic banks will be difficult to improve their position, expand networks, and show their performance more effectively (Chapra and Ahmed, 2002: 12). In addition, the results of testing this hypothesis are also in accordance with research conducted by Noordin and Kasim (2015). The results of their research found a significant positive correlation between Good Corporate Governance (GCG) which was proxied by the number of boards of directors and financial performance that was proxied by ROA in construction 
Iva Nur Azizah, Yayu Putri Senjani

companies. The results of this study are also consistent with the research of Haider, Khan, and Iqbal (2015) who found that Good Corporate Governance (GCG) variables were proxied on board size, number of meetings and size, audits, positive controls, regarding the financial performance of Islamic financial institutions in Pakistan.

Hypothesis testing on the effect of sharia compliance on financial performance and the effect of profit sharing ratio (PSR) on the financial performance of Islamic commercial banks has been carried out. Testing this hypothesis shows that the profit sharing ratio (PSR) which is a proxy of the sharia compliance variable does not affect the financial performance of Islamic banks which is proxied by return on assets (ROA). This means that mudharabah and musyarakah financing done by Islamic commercial banks do not have an impact on generating large profits. According to Rahma (2018), this was due to profit sharing financing being smaller than the buying and selling financing. Therefore, the contribution of revenue sharing obtained from the distribution of profit sharing financing cannot optimize the ability of Islamic banks to generate profits. The results of this study are not in accordance with stakeholder theory which states that the company will be able to maintain performance and maintain the company's survival by accommodating the wants and needs of stakeholders. This research is in accordance with Rahma's research (2018) which showed that profit sharing ratio (PSR) had no effect on return on assets (ROA).

From the hypothesis test on the effect of zakat performing ratio (ZPR) on the financial performance of Islamic commercial banks, it was found that the zakat performing ratio (ZPR) which is a proxy of the sharia compliance variable does not affect the financial performance of Islamic commercial banks which are proxied by return on assets (ROA). This is due to the relatively small amount of zakat issued by Islamic banks. The average zakat issued by Islamic commercial banks is 0.0041 of Islamic bank assets. This study is not in line with a research conducted by Fachrudin, Lubis, and Nasution (2018) which showed that zakat performing ratio (ZPR) had a negative effect on financial performance. 
Hypothesis testing on the effect of Islamic income ratio (IIR) on the financial performance of Islamic commercial banks results that the Islamic income ratio (IIR) which is a proxy of the sharia compliance variable affects the financial performance which is proxied by return on assets (ROA). Islamic Income Ratio (IIR) which is the result of the amount of sharia income divided by the amount of sharia income and non sharia income. The results of this study are not in accordance with research conducted by Nasution, Lubis, and Fachrudin (2018) who found that the Islamic income ratio (IIR) had no effect on the financial performance of Islamic commercial banks proxied by return on assets (ROA).

In addition, the results of this study are also not in accordance with research conducted by Rahma (2018). Rahma's research found that the Islamic income ratio (IIR) had no effect on return on assets (ROA). On the ratio side, Islamic financial ratios which are proxies of the sharia compliance variable also do not affect return on assets (ROA). Return on assets (ROA) is the total profit before tax is divided by total assets. This shows that the profit sharing ratio (PSR) variable, zakat performing ratio (ZPR), Islamic income ratio (IIR) have no effect on return on assets (ROA). Return on assets (ROA) is a non-sharia financial ratio. In conclusion, Islamic financial ratios have no effect on non-Islamic ratios.

According to Umam (2013), Islamic banks are developed as financial business institutions that run their business activities in line with the basic principles in Islamic economics. The purpose of Islamic economics for Islamic banks is not only focused on commercial goals that are reflected in achieving maximum profit, but also its role in providing broad welfare for the community. Contributions to participate in realizing public welfare is the role of Islamic banks in the implementation of social functions. The most visible social functions are realized through the activities of collecting and distributing zakat, donations, alms, grants and endowments. In addition, Islamic banks also issue zakat and provide financing. This social function is expected to be able to facilitate the allocation and distribution of social funds needed by the community. Thus, Islamic financial ratios that exist in Islamic 
Iva Nur Azizah, Yayu Putri Senjani

commercial banks do not have an impact on the profits derived by Islamic commercial banks.

Hypothesis testing on the role of intellectual capital in moderating the effect of good corporate governance and sharia compliance on the financial performance of Islamic commercial banks and the effect of intellectual capital in modernizing the effect of good corporate governance on the financial performance of Islamic commercial banks found that the intellectual capital variable weakened the relationship among the good corporate governance variables proxied by the composite value of GCG self assessment of financial performance proxied by return on assets (ROA). This means that intellectual capital weakens the positive influence on the financial performance of Islamic commercial banks. The better the level of good corporate governance and the better the existing human resources in Islamic banks, the weaker the financial performance of Islamic banks.

This finding is not in line with the main objectives of the Islamic economy which requires the realization of the economic welfare of the community. Contributions to participate in realizing public welfare is the role of Islamic banks in the implementation of social functions. When Islamic banks have good corporate governance and good intellectual capital, the Islamic banks will return to the objectives of Islamic commercial banks so that the variable of good corporate governance moderated by intellectual capital does not cause the return on assets (ROA) of Islamic banks to decline.

Hypothesis testing on intellectual capital in moderating the effect of profit sharing ratio (PSR) on the financial performance of Islamic commercial banks found that the intellectual capital variable did not modernize the relationship between the sharia compliance variable which is proxied by the profit sharing ratio (PSR) on the financial performance which is proxied by return on assets (ROA. This shows that the profit sharing ratio (PSR) has no effect on the financial performance of Islamic commercial banks. Likewise, after intellectual capital modernizing variables, the results show that there is no influence on the financial performance of Islamic commercial banks. 
Hypothesis testing on intellectual capital in moderating the effect of zakat performing ratio (ZPR) on the financial performance of Islamic commercial banks found that the intellectual capital variable did not modernize the relationship between the sharia compliance variable which was proxied with the zakat profit ratio (ZPR) on the financial performance of Islamic commercial banks which was proxied by Return on Assets (ROA). That zakat performing ratio (ZPR) does not affect the financial performance of Islamic commercial banks, after modernizing intellectual capital variable, Zakat performing ratio (ZPR) still does not affect the financial performance of Islamic commercial banks.

Hypothesis testing on the effect of intellectual capital in moderating the influence of Islamic income ratio (IIR) on the financial performance of Islamic commercial banks found that the intellectual capital variable modernized the relationship between the sharia compliance variable which was proxied by the Islamic income ratio (IIR) on the financial performance of Islamic commercial banks which was proxied by return on assets (ROA). This is due to the income obtained from Islamic bank products made by Islamic commercial banks giving an impact on the decline in profits of Islamic commercial banks, and the presence of intellectual capital variables also modernize the relationship between Islamic income ratio (IIR) on the financial performance of Islamic commercial banks.

Intellectual capital variables have an influence on the financial performance of Islamic commercial banks which areproxied by return on assets (ROA). The intellectual capital variable modernizes the effect of good corporate governance variables on the financial performance of Islamic banks but is weakening. The intellectual capital variable modernizes the influence of the Islamic income ratio variable on the financial performance of Islamic banks but is weakening. While intellectual capital does not moderate the shariah compliance variable which is proxied by profit sharing ratio (PSR), zakat performing ratio (ZPR), to return on assets (ROA) which is a proxy of the financial performance of Islamic commercial banks. This happens because the intellectual capital owned by human resources at Islamic banks is good. 
Iva Nur Azizah, Yayu Putri Senjani

The Islamic banks will comply and implement Islamic regulations (sharia compliance) and good corporate governance so that Islamic banks operate in accordance with Islamic economic goals that are not only focused on maximizing profit but also having a role in providing welfare for the community.

\section{Conclusion}

Good corporate governance proxied by the composite value of good corporate governance self-assessment has a positive effect on the financial performance of Islamic commercial banks. Sharia compliance which is proxied by the Islamic income ratio (IIR) affects the financial performance of Islamic commercial banks which is proxied by return on assets (ROA). Sharia compliance which is proxied by profit sharing ratio (PSR) has no effect on the financial performance of Islamic commercial banks which is proxied by return on assets (ROA). Sharia compliance which is proxied by zakat performing ratio (ZPR) does not affect the financial performance of Islamic banks.

Intellectual capital moderates the relationship between good corporate governance and the financial performance of Islamic commercial banks. However, intellectual capital weakens the relationship between good corporate governance and the financial performance of Islamic commercial banks. Intellectual capital does not moderate the relationship between sharia compliance which is proxied by profit sharing ratio (PSR) to the financial performance of Islamic commercial banks which is proxied by return on assets (ROA). Intellectual capital does not moderate the relationship between zakat performing ratio (ZPR) and the financial performance of Islamic commercial banks which is proxied by return on assets (ROA). Intellectual capital moderates the relationship between the Islamic income ratio (IIR) and the financial performance of Islamic commercial banks which is proxied by return on assets (ROA), but is able to weaken naturally.

Future studies are expected to be conducted and to add more periods, so that research results are more accurate; add other independent variables or 
The Role Of Intellectual Capital In ...

use the equitable distribution ratio (EDR), Islamic investment ratio (IIR), director - employee walfare ratio and others as a proxy for sharia compliance; and add the performance measurement of other Islamic banks that do not use the return on assets (ROA) proxy.

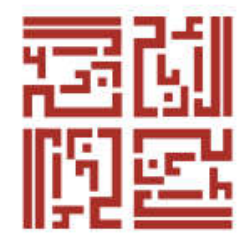

\section{References}

Aisjah, Sitti, et al. (2017). The Impact of Islamic Corporate Governance, Islamic Intellectual Capital, and Islamic Financial Performance on Sustainable Business Islamic Banks. International Journal of Economics and Financial Issues. 7, 316-323.

Ajija, Shochrul Rohmatul. (2011). Smart way to master Eviews. Jakarta: Salemba Empat.

Akguc, Serkandan Al Rahahleh, Naseem. (2018). "Effect of Sharia Compliance on Operating Performance: Evidence from GCC Countrie”. Routledge Taylor \& Farancis Group.

Ar-Rifa'i, Muhammad Nasib. (2012). Ringkasan Tafsir Ibnu Katsir, Jilid 3. Jakarta: Gema Insani.

Chapra, M Umerdan Ahmed, Habib. (2002). Corporate Governance Lembaga Keuangan Syariah. Jakarta: Bumi Aksara.

Effendi, Muh Arief. (2016). The Power of Good Corporate Governance Teori dan Implementasi. Jakarta: Salemba Empat.

Haider, Najib, Khan, Nabila dan Iqbal, Nadeem. (2015). Impact of corporate governance on firm financial performance in Islamic financial institution. International Letters of Social and Humanistic Sciences. 51.

Ilhami, Haniah. (2009). Pertanggungjawaban Dewan Pengurus Syariah Sebagai Otoritas Pengawas Kepatuhan Syariah bagi Bank Syariah. Mimbar Hukum. 21, 409-628.

Indriantoro, Nurdan Supomo, Bambang. (2014). Metodologi Penelitian Bisnis untuk Akuntansi dan Manajemen. Yogyakarta: BPFE-Yogyakarta.

Ismail, Ku Noor Izah Ku dan Al-Musali, Mahfoudh Abdul Karem. (2011). Intellectual Capital and Financial Performance of Banks in Bahrain. Journal of Business Management and Accounting. 1, 63-77. 
Iva Nur Azizah, Yayu Putri Senjani

Khan, Sajjad Nawazndan Ali, Engku Ismail.(2017). The Moderating Role of Intellectual Capital Between Enterprise Risk Management and Firm Performance: A conceptual Review. American Journal of Science and Humanities. 2 (1), 9-15.

Khotimah, Khusnul. (2017). Pandangan Berbasis Sumber Daya dalam Pembahsan Organisasi Ekonomi. Jurnal Manajemen dan Akuntansi. 5, 31-41.

Kurfi, Shafi'u Abubakar, Udin, Noraza Mat, dan Bahamman, Saleh Muhammad. (2017). The Impact of Intellectual Capital on The Financial Performance of Listed Nigerian Food Product Companies. Journal of Accounting and Taxtation. 9, 147-160.

Laporan Perkembangan Keuangan Syariah Indonesia (LPKSI). (2017).

M, Sitti Zakiah. (2017). Peran Kepatuhan syariah dalam memediasi Good Corporate Governance (GCG) terhadap Kinerja Keuangan pada Bank Umum Syariah. Research Gate.

Machmud, Amir dan Rukmana. (2010). Bank Syariah: Teori, Kebijakan, dan Studi Empiris di Indonesia. Jakarta: Erlangga.

Nasution, Ananda Anugrah, Lubis, Ade Fatma, dan Fachrudin, Khaira Amalia. (2018). Sharia Compliance and Islamic Social Reporting on Financial Performance of Indonesian Sharia Banks. Atlantis Press. 292, 640-644.

Ni Wayan Rina Winahyudan Ni Putu Sri Harta Mimba. Intellectual Capital sebagai Pemoderasi Pengaruh Debt to Equity Ratio dan Ukuran Perusahaan pada Profitabilitas perusahaan Property dan Real Estate. E-Jurnal Akuntansi Universitas Udayana. 23, 734-760.

Noordin, Nazrul Hazizi dan Kassim, Salina. (2015). Corporate Governance and Financial Performance: Empirical Evidence from Public Listed Contruction Companies in Malaysia. Research Gate.

Nurhisam, Luqman. (2017). Kepatuhan Syariah (Syariah Compliance) dalam Industri Keuangan Syariah. Jurnal Hukum IUS. 23, 77-96.

Ozkan, Nasif, Cakan, Sinan, dan Kayacan, Murad. (2016). Intellectual Capital and Financial Performance: A study of Turkish Banking sector. Borsa Istanbul. 17, 190-198.

Pepis, Scott dan Jong, Pieter de. (2018). Effects of Shariah-Complianct bussines practices on long-term financial performance. Jurnal Elsevier. 53, 254-267. 
Rahma, Yusro. (2018). The Effect of Intellectual Capital and Islamic Performance Index on Financial Performance. Jurnal Ilmu Akuntansi. 11, 105-116.

Shahul, Hameedibn Mohamed Ibrahim, et al. (2004). Alternative Discolsure\& Performance Measures for Islamic Bank. Journal of Financial and Accounting. 4, 1-23.

Shahul, Hameed Mohamed Ibrahim, A.H Fatima, Sheila Nu Nu Htay. (2004). Corporate Governance and Performance: A Comparative Study of Shariah Approved and Approved Companies on Bursa Malaysia. Journal of Financial and Accounting. 4, 1-23.

Siswanti, Indra, dkk. (2017). The Impact of Islamic Corporate Governance, Islamic Intellectual Capital and Islamic Financial Performance on Sustainable Business Islamic Bank. International Journal of Economics anda Financial Issues. 7, 316-323.

Ulum, Ihyatul. (2009). Intellectual Capital Konsep dan Kajian Empiris. Yogyakarta: Graha Ilmu.

Umam, Khaerul. (2013). Manajemen Perbankan Syariah. Bandung: Pustaka Setia.

Wafik, Grais dan Matteo Pellegini. (2006). Corporate Governance Institution Offering Islamic Financial Services. Research Gate.

Widarjono, Agus. (2007). Ekonometrika: Teori dan Aplikasi untuk Ekonomi dan Bisnis, Edisi Kedua. Yogyakarta: Ekonisia FE Universitas Islam Indonesia.

Winarno, Wing Wahyu. (2011). Analisis Ekonometrika dan Statistika dengan Eviews, Edisi 3. Yogyakarta: UPP STIM YKPN. 
Iva Nur Azizah, Yayu Putri Senjani

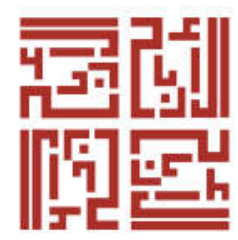

AL-ARBAH | 68 